\title{
KOMUNIKASI ANTAR BUDAYA PADA KOMUNITAS PERCA (STUDI FENOMENOLOGI)
}

\author{
Maria Eva Rosalyn ${ }^{1}$, Yohanes Arie Kuncoroyakti ${ }^{2}$ \\ ${ }^{1,2}$ Program Studi Ilmu Komunikasi, London School of Public Relations \\ Email: evayorian@gmail.com
}

Diterima : 08 Januari 2019

Disetujui : 14 Januari 2019

Diterbitkan : 26 Februari 2019

\begin{abstract}
Abstrak
Penelitian ini dilakukan untuk melihat komunikasi antar budaya yang terjadi dalam pasangan yang tergabung dalam komunitas PerCa Indonesia, khususnya di wilayah Jabodetabek. Metode penelitian yang dilakukan adalah metode kualitatif dengan fenomenologi komunikasi sebagai dasar penelitian. Komunitas PerCa merupakan komunitas yang beranggotakan pasangan dengan kewarganegaan yang berbeda. Perbedaan budaya yang ada dalam komunitas pasangan suami istri bukan menjadi hal terpenting dalam komunikasi melainkan sikap untuk saling memahami dan menerima. Kemampuan inilah yang seringkali dilakukan oleh pasangan dan menjadikan kebiasaan. Penelitian ini juga melihat bahwa komunikasi budaya yang terjadi diantara pasangan tersebut menimbulkan sebuah komunikasi transaksional, Selain itu muncul juga sebuah budaya baru yang dihasilkan. Budaya baru tersebut terbentuk karena budaya dari salah satu pasangan menjadi lebih dominan, hal tersebut tidak mempengaruhi relasi yang terjadi diantara mereka.
\end{abstract}

Kata Kunci : Komunikasi Antar Budaya, Pasangan, Perkawinan

\begin{abstract}
This research was conducted to see the intercultural communication that occurs in couples who are members of the Indonesian PerCa community, especially in the Jabodetabek area. The research method used is a qualitative method with phenomenology of communication as the basis of research. The PerCa community is a community consisting of couples with different citizenship. Cultural differences that exist within the community of married couples are not the most important thing in communication but the attitude to understand and accept each other. This ability is often done by couples and make habits. This study also saw that cultural communication that occurred between the pairs gave rise to a transactional communication, in addition a new culture emerged. The new culture is formed because the culture of one partner becomes more dominant, it does not affect the relationships that occur between them.
\end{abstract}

Key Word : Communcation Between Culture, Relationship, Married

\section{PENDAHULUAN}

Globalisasi berkembang dan menyebar ke seluruh penjuru dunia, termasuk didalamnya. Perubahan terjadi diseluruh aspek kehidupan masyarakat, termasuk didalamnya agama, kebudayaan, teknologi dan sosial. Globalisasi yang terjadi di Indonesia menyebabkan perubahan sosial yang terjadi dalam masyarakat. Kota besar di Indonesia menjadi pusat sumber ekonomi sehingga masyarakat dari daerah pindah ke kota besar. Fenomena ini terjadi juga dalam lingkup internasional, dimana banyak warga negara asing melihat Indonesia sebagai salah satu sumber ekonomi dan peluang lain. 
Peneliti melihat bahwa perubahan ini terjadi salah satunya di ibukota Jakarta, dimana pada tahun 2015 terdapat jumlah Warga Negara Asing (WNA) sebanyak 1966 dengan WNA pria sebesar 1289 dan wanita sebesar 677. (http://data.jakarta.go.id). Warga negara asing tinggal di Jakarta dijadikan sebagai obyek penelitian karena DKI Jakarta merupakan pusat pemerintahan dan menjadi salah satu pusat perekonomian di Indonesia. Warga Negara asing yang tinggal di DKI Jakarta dalam kesehariannya memiliki relasi sosial dengan Warga Negara Indonesia. Komunikasi dapat terjadi diantara mereka.

Komunikasi merupakan sebuah proses dimana sebuah interaksi antara komunikan dan komunikator yang melakukan pertukaran pesan didalamnya yang terjadi secara langsung maupun tidak langsung, komunikasi sendiri bisa dikatakan merupakan hal yang paling krusial dalam kehidupan ini. Komunikasi dalam penelitian ini bukan hanya terjadi antara individu yang satu dengan lain dalam konteks sama, komunikasi seringkali muncul dalam beragam perbedaan budaya, sosial, agama dan ras.

Komunikasi antar budaya sudah berlangsung di Indonesia sejak ratusan tahun yang lalu dengan masuknya pedagang Cina, India, Eropa, dsb. Masuknya pedagang mengakibatkan perubahan sosial dan budaya masyarakat di Indonesia. Komunikasi antarbudaya pada dasarnya mengkaji bagaimana budaya berpengaruh terhadap aktivitas komunikasi: apa makna pesan verbal dan nonverbal menurut budaya-budaya bersangkutan, apa yang layak dikomunikasikan, bagaimana cara mengkomuni-kasikannya (verbal dan nonverbal) dan kapan mengkomunikasikannya (Mulyana, 2005: xi).

Komunikasi budaya dapat terjadi apabila terdapat perpindahan tempat dari etnis yang berbeda ke wilayah atau daerah yang memiliki etnis berlainan. Kondisi ini terjadi ketika di Jakarta menerima masuknya WNA dari negara yang berbeda. Warga Negara Asing yang masuk dan bermaksud untuk menetap di Jakarta perlu melakukan beragam adaptasi, dan disanalah muncul komunikasi antar budaya dimana ini sering terjadi antar WNA dengan WNI.

Relasi yang terjadi dalam komunikasi antar budaya antar WNA dengan WNI beberapa diantaranya berlanjut sehingga mereka kemudian membentuk sebuah keluarga. Perkawinan campuran di sini dapat diartikan sebagai perkawinan antar bangsa, dimana perkawinan ini menjadi wadah akulturasi budaya. Perundang-undangan di Indonesia, perkawinan campuran didefinisikan dalam UU No.1 Tahun 1974 tentang Perkawinan, pasal 57: "Yang dimaksud dengan perkawinan campuran dalam Undang-undang ini ialah perkawinan antara dua orang yang di Indonesia tunduk pada hukum yang berlainan, karena perbedaan kewarganegaraan dan salah satu pihak berkewarganegaraan Indonesia."

Keluarga yang terbentuk atas dasar perbedaan budaya ini kemudian bergabung menjadi sebuah komunitas, PerCa menjadi sebuah komunitas dimana anggotanya adalah WNA dengan WNI. PerCa Indonesia yang didirikan sejak tahun 2008 lalu ini senantiasa mengajak anggotanya untuk aktif berkegiatan di lingkungan sekitar. Sedikitnya, 250 anggota PerCa Indonesia merupakan wanita atau pria WNI yang menikah dengan WNA. Penelitian ini melihat bagaimana komunikasi antar budaya yang terjadi antar anggota komunitas PerCa Indonesia?

\section{METODOLOGI PENELITIAN}

Penelitian ini menggunakkan metode kualitatif dimana nantinya akan diharapkan memperoleh pemahaman secara mendalam mengenai bagaimana pola komunikasi sangat berpengaruh dalam pernikahan. Penelitian jenis ini dipilih karena fokus kajian adalah fenomena komunikasi yang bersifat unik dalam mencerminkan realitas social dan perilaku manusia. Menurut Strauss dan Corbin dalam Cresswell (1998 : 24), Penelitian kualitatif 
adalah jenis penelitian yang menghasilkan penemuan yang tidak dapat dicapai dengan menggunakkan prosedur statistik atau cara lain dari kuantifikasi.

Penelitian kualitatif bersifat deskriptif dan cenderung menggunakan analisis induktif. Peneliti bertolak dari data, serta memanfaatkan teori yang ada sebagai bahan penjelas, kemudian berakhir pada hipotesis atau teori. Penelitian kuantitatif berangkat dari teori menuju data dan berakhir pada penerimaan atau penolakan terhadap teori yang digunakan. Penelitian kualitatif digunakan untuk menemukan hipotesis atau teori, sedangkan penelitian kuantitatif digunakan untuk menguji hipotesis (Sugiyono, 2013: 39).

Pendekatan kualitatif merupakan pendekatan yang berdasarkan pada kenyataan lapangan dan apa yang dialami responden. (Sudjarwo, 2001: 25). Penelitian kualitatif adalah salah satu prosedur penelitian yang menghasilkan data deskriptif berupa ucapan atau tulisan dan perilaku orang yang diamati. (Bogdan, 1992: 21 - 22) Pendekatan kualitatif pada pasangan dengan budaya yang berbeda diharapkan menghasilkan sebuah uraian mendalam perilaku kelompok (PerCa) yang dikaji dari sudut pandang yang utuh dan komprehensif.

Hakikat penelitian ini menggunakkan penelitian subjektif, dimana terdapat pemahaman mendasar bahwa realitas yang ditelaah dalam hal ini realitas komunikasi bersifat ganda, rumit, semu, dinamis, dikonstruksikan, holistic dan sejatinya kebenaran bersifat relatif. Manusia yang terlibat dalam proses komunikasi adalah subjek yang aktif, kreatif, dan memiliki kemauan bebas yang mampu mengendalikan seluruh proses komunikasi daripada sebaliknya (Mulyana, 2002:34- 35).

Metode kualitatif untuk penelitian komunikasi yaitu melalui pendekatan fenomenologi, etnometodologi, interaksi simbolik, etnografi dan studi kultural. Lima pendekatan itu sering disebut sebagai paradigma interpretif (interpretive paradigm) (Lindlof, 1995: 27-58). Penelitian ini menggunakkan pendekatan fenomenologi dalam melihat komunikasi antar budaya anggota komunitas PerCa Indonesia. Fenomenologi berarti membiarkan segala sesuatu menjadi nyata sebagaimana aslinya tanpa memaksakan kategori peneliti terhadapnya. (Littlejohn, $1996: 204$ )

Pengumpulan data dalam penelitian ini menggunakkan metode yang digunakkan dalam pendekatan fenomenologi, yang dikenal dengan metode "A Data Collection Circle" (Cresswell,1998: 109-135). Metode tersebut dimulai dengan menentukan lokasi atau individu, penelitian ini lebih menitik beratkan pada individu yang menjadi anggota komunitas PerCa khususnya yang berlokasi di wilayah DKI Jakarta.

Tahap selanjutnya adalah melakukan pendekatan dengan "Gaining Access and Making Rapport" (Creswell, 1998:130). Proses pendekatan ini dilakukan peneliti dengan berkunjung saat terdapat acara kumpul anggota komunitas PerCa. Kedekatan awal antar peneliti dengan anggota komunitas perlu dibangun dan ini tentunya membutuhkan kesabaran dan perhatian tersendiri. Tahap terakhir adalah dengan membangun Rapport antara peneliti dengan anggota komunitas dengan mengunjungi tempat tinggal mereka.

Pengumpulan data tersebut tentunya didukung oleh triangulasi data, triangulasi berarti suatu teknik pemeriksaan keabsahan data yang dilakukan dengan cara memanfaatkan hal-hal (data) lain untuk pengecekan atau perbandingan data (Moleong, 2001:178). Triangulasi pada hakikatnya merupakan pendekatan multimetode yang dilakukan peneliti pada saat melakukan penelitian, mengumpulkan, dan menganalisis data. Ide dasarnya adalah bahwa fenomena yang diteliti dapat dipahami dengan baik, sehingga diperoleh kebenaran tingkat tinggi jika didekati dari berbagai sudut pandang seperti sumber, peneliti, metode dan teori.

\section{HASIL DAN PEMBAHASAN}

Komunitas PerCa Indonesia terbagi dalam beberapa wilayah seperti; Jakarta, Batam, Bali, Balikpapan, Makasar, Jawa Timur, Jawa Tengah. Sasaran yang ingin dicapai oleh 
komunitas ini salah satunya adalah Meningkatkan kesejahteraan dan perlindungan WNI dalam perkawinan campuran, anak dan keluarga perkawinan campuran (http://www.percaindonesia.com/)

Penelitian ini menitikberatkan pada Komunikasi antar budaya dalam komunitas PerCa. Manusia membutuhkan komunikasi bukan sekedar untuk menyampaikan atau menerima informasi, melainkan juga untuk membina interaksi yang terjadi. Interaksi sosial antar manusia melalui komunikasi dapat dilakukan dengan komunikasi verbal maupun non verbal, dengan demikian perbedaan budaya dan fisik bukan menjadi halangan untuk menyampaikan pesan. Menurut Onong Ochana sebagaimana dikutip oleh M. Burhan Bangin, "komunikasi sebagai proses komunikasi pada hakekatnya adalah proses penyampaian pikiran atau perasaan oleh seseorang (komunikator) kepada orang lain (komunikan). Pikiran bisa merupakan gagasan informasi, opini, dan lain-lain yang muncul dari benaknya. Perasaan bisa berupa keyakinan dan kegairahan, dan sebagainya yang timbul dari lubuk hati”. (Bungin, 2006: 31)

Ketika memilih untuk melakukan pernikahan campur, maka yang terbesit di pikiran kita adalah pencampuran budaya yang terjadi didalamnya. Kondisi ini akan terdengar sulit bagi orang orang yang baru ingin menjalani atau bahkan tertutup terhadap budaya baru. Ibu Melva memberikan pendapatnya tentang pernikahan campur dan budaya yang terlibat didalamnya; "Sebetulnya itu terbilang kepada personal choices ya , personal choices karena apa namanya kita kan sudah tahu kita menikahnya dengan apa, budaya mana itu kita harus masing masing mempelajari dan respect that culture, itu harus text to tango ya, kalo hanya satu orang maka itu akan timpang dan itulah yang terjadi, apa namany .. perpisahan karena tapi perpisahanny bukan karena budaya sebetulnya, biasanya ... i dont know its too sensitive to us but....

Budaya itu tidak pernah memisahkan dua orang, tetapi itu selalu hal hal kecil yang mungkin lama lama jadi besar" Pencampuran budaya juga merupakan hal yang sulit dilakukan oleh pasangan kawin campur, hal ini dikarenakan oleh perbedaan dari banyak hal yang ada didalam diri tiap tiap pasangan.

Komunikasi antar budaya (intercultural communication) adalah proses pertukaran pikiran dan makna antara orang-orang berbeda budaya. Komunikasi antarbudaya pada dasarnya mengkaji bagaimana budaya berpengaruh terhadap aktivitas komunikasi, apa makna pesan verbal dan nonverbal menurut budaya-budaya bersangkutan, apa yang layak dikomunikasikan. Bagaimana cara mengkomunikasikannya, kapan mengkomunikasikannya dan sebagaimana. (Syaiful, 2009: 198). Proses pertukaran pesan yang terjadi, maka akan memasuki tahap tinggi, yaitu tahap transaksional. Komunikasi transaksional meliputi tiga unsur penting yakni; (1) keterlibatan emosional yang tinggi, yang berlangsung terus menerus dan berkesinambungan atas pertukaran pesan; (2) peristiwa komunikasi meliputi seri waktu, artinya berkaitan dengan masa lalu, kini, dan yang akan datang; dan (3) partisipan dalam komunikasi antarbudaya menjalankan peran tertentu. (Liliweri, $2011: 24$ ).

Terlebih kebudayaan yang dibawa sejak lahir sudah sangat berbeda, Maka seperti yang Ibu Melva ucapkan diatas, banyak orang yang berfikiran bahwa perbedaan budaya dapat menyebabkan perpisahan. Budaya tidak pernah menjadi sebab dalam suatu perpisahan.

"Tapi komunikasi itu tadi, kan mereka ilmunya ilmu komunikasi.. jadi how to communicate your thoughts, your feelings, your situation or whatever circumtances.. itu harus selalu dikomunikasikan, mungkin itu intinya .. jadi komunikasi yang baik , not because of language, culture or... tapi its more of a human communication yah dan juga ada chemistry kayanya yah, hahah sorry" Ibu Melva menjelaskan diatas bahwa yang terpenting dalam pernikahan baik itu campur atau tidak adalah komunikasi, sedangkan dalam pernikahan campuran kita mengenal Komunikasi Antar Budaya. Proses penyesuaian budaya 
ini dikenal dengan konsesus, tidak semua pasangan yang menjadi Informan penelitian, mengakui telah melakukan kesepakatan dengan pasangan masing - masing ketika sebelum meresmikan pernikahan. Proses terjadinya suatu konsensus bisa cepat, tetapi tidak menutup kemungkinan melalui proses yang lama. (Hadawiyah, 2016)

Komunikasi antar budaya berperan dalam menyatukan kebudayaan yang berbeda ini. Melalui komunikasi, pencampuran budaya adalah hal yang mungkin dilakukan, hal ini dikemukakan oleh Leo Pechler dan Yessi Suharstati sebagai berikut;

"Baik baik saja sih awal kita berkomunikasi nya,namun masih sedikit menggunakan bahasa yang "campur" karena dia sendiri juga awalnya tidak terlalu fasih dalam berbahasa Indonesia dan lalu makanya saya mix saja biar bisa nyambung bahasanya antara saya dan dia." (Leo) "Ya kalo perbedaan secara budayanya sih lumayan cukup banyak ya,karena kan saya juga awalnya kurang paham mengenai budaya2 apa saja yang biasa dia lakukan setiap harinya gitu. Lalu kalau dalam kendala berkomunikasi nya sih kita sejauh ini fine 2 aja karena saling bekerja sama untuk menjalin komunikasi yang efektif aja sih diantara kita berdua." (Yessi)

Fungsi dari komunikasi antar budaya adalah, membangun budaya lain merupakan satu hal yang sangat penting dalam membangun komunikasi yang efektif. Artinya, pemahaman dan penerimaan yang dilakukan terhadap budaya yang dimiliki oleh masyarakat lain yang memiliki budaya yang berbeda menjadi satu dasar dalam membangun komunikasi yang efektif. Konteks penerimaan budaya ini berkaitan dengan tipe perkawinan, Anna Fitzpatrick mengidentifikasi tiga dimensi yang dapat membedakan tipe-tipe perkawinan. Pertama, tipe ketergantungan, yaitu adanya kebutuhan untuk berbagi rasa satu sama lain. Kedua, tipe ideologi, yaitu perkawinan berjalan sesuai dengan kepercayaan tradisional dan nilai-nilai yang dianut oleh pasangan. Dan ketiga, tipe komunikasi, yaitu cara yang dilakukan oleh pasangan untuk mengatasi konflik dalam perjalanan perkawinan. (Verderber \& Verderber, 1998: 383). Tipe perkawinan dalam tiga dimensi tersebut dalam perubahan waktu dapat berubah seiring dengan perhatian dan pola komunikasi yang dilakukan oleh pasangan.

Penerimaan terhadap budaya satu sama lain menjadi faktor pendukung dalam komunikasi antar budaya. Dengan begitu diri kita terbuka dengan budaya orang lain sehingga bisa memahami budaya tersebut, baik dari bahasanya atau kebiasaannya.

Komunikasi antar budaya merupakan hal yang penting didalam perkawinan campur, sehingga kedua pasangan dapat mengerti satu sama lain. Kesulitan juga dapat ditemukan di diri anak yang terlahir dari pasangan yang berbeda budaya, pendapat ini dikemukakan oleh Ibu Melva. "Jadi itu tadi kesulitan anak yang bahasa indonesia duluan, bahasa indonesia dan inggris kemudian sekarang dia bahasa perancis itu campur adu, gitu loh."

Bahasa menjadi salah satu kesulitan tersendiri didalam perkawinan campur, terutama dalam perkawinan yang masih baru, sehingga masih perlu banyak penyesuaian. Ditambah dengan adanya anak yang orang tuanya berbeda bahasa dapat menjadi kesulitan tersendiri. Ketika seorang anak atau bahkan pasangan dihadapkan dengan 2 bahasa atau bahkan lebih, maka itu seperti menjadi peraduan bahasa yang dapat menyulitkan. Beulah Rohrlich menyatakan, bahwa dalam keluarga kawin campur komunikasi merupakan isu utama yang lazim muncul.

Rohrlich memberikan beberapa alternatif dalam upaya penyesuaian: Penyesuaian satu arah (one way adjustment) dimana salah satu mengadopsi pola budaya pasangannya. Konteks 2 bahasa yang berbeda dapat dilakukan dengan berusaha untuk memahami salah satu budaya pasangan, dan kondisi ini dilakukan setiap waktu. Penyesuaian alternatif (alternative adjustment), pada satu kesempatan salah satu budaya diterapkan, tapi pada kesempatan lain budaya lainnya diterapkan. Kondisi ini juga diterapkan dalam penggunaan bahasa, seringkali ditemukan adanya penyesuaian alternative bila dirumah menggunakkan bahasa Indonesia dan diluar menggunakkan bahasa Inggris (Dodd, 1998: 71) 
Hambatan yang tidak dapat dilalui oleh pasangan dalam penelitian ini, bahasa pun bisa menjadi suatu tantangan bagi pasangan kawin campur dalam menyatukan budaya masing masing, karena dengan belajar bahasa negara lain, kita sudah mempelajari budaya itu sendiri. "For example my husband is not a good example because he doesnt speak indonesian fluently and not technically, but bahasa indonesia pasar itu dia bisa. Caring on conversation.. fine tapi begitu presentasi.. tangkai ..langsung tidak bisa , nah jadi.. tapi ada yang menikah dengan orang amerika juga. Seem a years yah, he hes been here for 30 .. more than 35 years dan dia lebih javanese pada istrinya yang orang jawa iya kebalik ,yang itu tuh thats another...another apa namanya, ini ya karena mungkin dia , waktu awal itu memang dia lebih lama tinggal di jepang. I told you that, jepang ama jawa kan mirip dari unggak-ungguk, you know.. the culture.. terus ya itu tadi, bahasa. Jadi dia lebih ke jawajawaan dari sikap dan ini nyaaa. "

Ketika mempelajari budaya dari seseorang, terlebih perkawinan campur kita malah bisa lebih mendalami budaya tersebut dibandingkan dengan pasangan kita yang memiliki budaya itu semenjak lahir. Ibu Melva memberikan contoh bahwa ada pasangan amerika dan jawa, lalu mereka tinggal di Indonesia dan orang amerika tersebut jauh lebih Jawa dibandingkan dengan istrinya. Penyesuaian campuran (mixing adjustment): kombinasi dari dua budaya yang sepakat untuk diadaptasi dikemukakan oleh Beulah Rohrlich (Dodd, 1998: 71) Pemahaman ini juga bukan berarti WNA lebih Indonesia dibanding WNI, beberapa diantaranya juga WNI yang lebih menguasai bahasa asing, Perancis misalnya.

Komunikasi antar budaya dalam pasangan dapat menyebabkan munculnya alkulturasi. Dimana akulturasi dapat menghasilkan kebudayaan baru yang merupakan pencampuran dari dua kebudayaan yang berbeda. Konteks alkuturasi ini dikemukakan pula oleh Leo, sebagai berikut;. "Yaa seiring berjalan nya waktu jika mensatukan dua individu yang berbeda itu nantinya pasti akan dapat menyesuaikan dengan sendirinya sih menurut saya..Dan yes,Akulturasi budaya itu sangat baik sekali menurut saya. Karena saya sudah merasakan dampak nya secara langsung bersama Yessi."

Akulturasi dapat berdampak baik dalam perkawinan campur, karena hal teresebut mendorong pasangan untuk menciptakan penyesuaian diri, sehingga keharmonisan rumah tangga dapat tercipta didalamnya. Komunikasi antar budaya dan akulturasi menjadi sebuah bagian yang saling berkaitan. Akulturasi adalah suatu konsep mengenai proses sosial yang timbul bila suatu kelompok manusia dengan suatu kebudayaan tertentu dihadapkan dengan unsur-unsur kebudayaan asing yang lambat laun diterima dan diolah ke dalam kebudayaan sendiri tanpa menyebabkan hilangnya kepribadian kebudayaan itu sendiri (Koentjaraningrat, 1990: 248).

Proses alkulturasi budaya ini seringkali menimbulkan konflik, dan salah satunya adalah karena adanya misscommunication diantara kedua belah pihak yang diakibatkan karena perbedaan etnis dan sulit nya menyesuaikan kondisi tersebut. Penelitian ini menunjukkan, keterbukaan komunikasi antar pasangan suami istri yang baik belum tentu bisa mengurangi intensitas konflik pada proses eskalasi hubungan dalam perkawinan. Faktor gaya komunikasi pada etnis Jawa dengan Papua (mengontrol, agresif, koersif, dominasi dan bersifat rasis) memberi kontribusi untuk menentukan munculnya konflik. (Rostini, 2016)

Akulturasi dapat menyebabkan dominannya satu budaya yang lebih unggul. Hal ini dapat terjadi ketika pasangan terlalu memaksakan budayanya, atau ketika kita memutuskan untuk tinggal di daerah yang kental dengan budaya tersebut atau mempelajarinya lebih dalam, Seperti yang Leo sampaikan :

"Hmm ya pastinya kita cukup netral sih untuk membahas masalah itu,karena saya memberitahu kepada anak saya mengenai Budaya saya beserta keluarga saya,dan tak luput juga budaya dari Istri saya. Namun untuk sekarang sih mungkin lebih dominan nya ke 
budaya Indonesia sih ya karena saya juga sudah menetapkan untuk tinggal disini." Alkuturasi yang terjadi dalam komunikasi antar budaya dapat menghilangkan stereotype. Menurut Kornblum, Stereotipe merupakan citra yang kaku mengenai suatu kelompok ras atau budaya yang dianut tanpa memperhatikan kebenaran citra tersebut. (Mulyana, 2006 : 2180). Konteks stereotipe lebih mengacu pada kecenderungan bahwa sesuatu yang dipercayai orang bersifat terlalu menyederhanakan dan tidak peka terhadap fakta objektif, Hal ini kemudian menimbulkan sebuah prasangka. Individu tentunya dapat memiliki prasangka (Stereotipe) terhadap individu lain, walaupun tidak semua prasangka bersifat negatif karena ada yang bersifat positif.

Konteks stereotype seperti yang dikemukakan oleh Elina mengatakan walaupun dia keturunan India-cChina tetapi bahasa yang diturunkan oleh keluarganya adalah bahasa mandarin. Walaupun ayahnya seorang India tetapi ayahnya besar dalam lingkungan yang mayoritasnya orang china; "yeah, my dad he is pure indian, but his whole family speak chinese because they grew up in chinese village" Karena dibesarkan dengan bahasa mandarin yang lebih dominan dari bahasa tamil, bahasa nasional india, akhirnya Elina kesulitan dalam pengucapan bahasa tamil. Dan setiap dia berbicara dalam bahasa India, kata kata yang didengar pun tidak jelas " $i$ did tried to speak tamil but whatever $i$ speak nobody understand, the indian cannot understand" Bu Melva menjelaskan bahwa ada yang namanya language interference atau gangguan bahasa, yang menurut bu Melva dalam penjelasannya adalah adanya kesulitan mempelajari bahasa lain berdasarkan bahasa asli yang digunakan. "ada yang namanya language inteference dimana Inggris dengan perancis itu susah, susah untuk digabungkan, sama dengan kalo orang berbahasa Indonesia dengan berbahasanya Spanyol, itu juga ada language interference-nya terlalu ini, believe it or not bahasa Jepang dengan bahasa Jawa juga sama kalo orang itu ya, dua bahasa itu itu kalo tiba tiba harus berbicara orang jawa tetap harus belajar bahasa Jepang untuk kesulitan.. tingkat kesulitannya akan lebih tinggi daripada orang batak belajar bahasa Jepang, contoh jadi. Jadi ada namanya language interference",

Konteks akulturasi budaya diungkapkan pula oleh dengan Jonathan, dalam penggabungan bahasa yang diajarkan oleh orang tua Jonathan tidak ada hambatan. Karena bahasa utama Jonathan yaitu bahasa perancis masih digunakan sampai dia dewasa sebagai berikut :

"Bu Melva : when you were little it was okay ,apa namanya untuk dua

bahasa sekaligus karena itu that was just french.

Jonathan : iya

$\mathrm{Bu}$ Melva : and then mungkin indonesia hanya sama pembantu atau ibu tentunya

Jonathan: iya, betul

Bu melva : tapi not, not intensif ya

Jonathan : iya

$\mathrm{Bu}$ Melva : sesudah umur enam tahun baru intensif

Jonathan : baru intensif"

Sebagai orang tua dari dua kebudayaan yang berbeda, mereka harus memilih mana budaya yang harus ditanamkan terlebih dahulu. Dalam wawancara kami dengan Leo dan Yessi mereka memilih memasukkan budaya Indonesia dulu karena dominannya tempat tinggal mereka di Indonesia " Hmm ya pastinya kita cukup netral sih untuk membahas masalah itu,karena saya memberitahu kepada anak saya mengenai Budaya saya beserta keluarga saya,dan tak luput juga budaya dari Istri saya. Namun untuk sekarang sih mungkin lebih dominan nya ke budaya Indonesia sih ya karena saya juga sudah menetapkan untuk tinggal disini." Pemilihan budaya ini dalam teori dikenal dengan kompromi midpoin 
(midpoint compromise), Sehingga kedua pihak memutuskan untuk menentukan posisi masing-masing sebagai jalan keluar dari perbedaan budaya. (Dodd, 1998: 71)

Penelitian ini melihat proses alkulturasi yang terjadi dalam komunikasi antar budaya pasangan dalam komunitas PerCa sebagai sebuah perspektif sistem. Bagian dasar dari sistem dapat terlihat ketika seorang individu berusaha berkomunikasi secara aktif dan mengharapkan dapat berkomunikasi dengan lingkungannya. Hal serupa dapat Leo yang berusaha untuk memahami budaya Indonesia, sebagai lingkungan tinggalnya. Belajar untuk memahami lingkungan juga dilakukan oleh ibu Melva yang berusaha untuk memahami bahasa jawa, dimana kemampuan ini dapat membantu juga untuk berkomunikasi dengan lingkungannya.

\section{PENUTUP}

Berdasarkan penelitian dan temuan penulis pada bab sebelumnya, maka penulis membuat kesimpulan. Anggota komunitas PerCa adalah pasangan suami istri dengan perbedaan kewarganegaraan. Perbedaan inilah yang mendasari perlunya komunikasi antar budaya diantara mereka. Budaya tidak dapat memisahkan perkawinan diantara pasangan tersebut, melainkan lebih pada diri pribadi dari masing masing. Penyampaian pesan dari suami ke istri ataupun ke anak yang dilakukan dari lubuk hati menjadikan komunikasi lebih efektif, hal ini terjadi pula dari istri ke suami atau anak. Sikap untuk mau mendengarkan dan berusaha untuk memahami pesan yang disampaikan oleh pasangan dapat juga menjadi salah satu pendukung dalam komunikasi yang efektif diantara mereka.

Komunikasi antar budaya yang dilakukan oleh pasangan suami - istri dapat berperan dalam menyatukan perbedaaan diantara mereka. Kemampuan untuk mau menerima pasangan yang berbeda budaya sebagai sebuah kebiasaan keseharian baik dari aspek bahasa maupun kebiasaan menjadi bagian penting dalam komunikasi antar budaya. Kondisi ini kemudian menimbulkan sebuah komunikasi transaksional dimana masing masing pasangan memiliki peran penting dalam komunikasi, peran ini berguna dalam komunikasi antar budaya.

Faktor kompromi antar pasangan dalam komunitas PerCa menjadi salah satu faktor penting dalam menjaga harmonisasi keluarga. Kompromi ini dilakukan dalam berbagai hal kehidupan, kompromi menjadi bagian penting dari komunikasi. Komunikasi adalah proses yang dinamis dan terus berubah merupakan bagian dari konteks yang lebih luas. Perubahan ini dilakukan oleh pasangan saat mereka menikah.

Komunikasi antar budaya pada pasangan anggota Komunitas PerCa dapat menyebabkan munculnya sebuah kebudayaan baru, dimana kebudayaan Indonesia dapat bercampung dengan budaya dari luar negeri. Munculnya budaya baru ini biasanya terjadi dimana salah satu pasangan memiliki budaya dominan yang lebih unggul. Pasangan suami istri beberapa diantaranya dominasi budaya lebih banyak dianut budaya masyarakat Indonesia, sehingga seringkali muncul opini dimana orang Amerika lebih Jawa dibandingkan orang Jawa itu sendiri. Alkultasi dapat berjalan dengan baik karena masing masing pasangan berusaha untuk menciptakan penyesuaian diri agar rumah tangga mereka dapat harmonis.

\section{REFERENSI}

Aloysius Liliweri, 2011. Dasar-Dasar Komunikasi Antarbudaya. Yogyakarta: Pustaka Pelajar.

Bogdan, R \& Biklen S. 1992, Qualitative Research for Education. Boston,MA: Allyn and Bacon 
Cresswell, J. 1998. Research Design Qualitative \& Quantitative Approach. Thousand Oaks, CA: Sage Publication

Dodd, Carley H, 1998. Dynamics of Intercultural Communication (Fifth Edition). USA: The McGraw-Hill Companies, Inc

Koentjaraningrat. 1990. Pengantar Ilmu Antropologi. Jakarta: Rineka Cipta

Lindlof, Thomas R., 1995, Qualitative Communication Research Methods, Sage Publications, California USA.

Littlejohn, Stephen W., 1996, Theories of Human Communication, fifth edition, Wadsworth Publishing Company, Belmont California

Mohammad Shoelhi, 2015. Komunikasi Lintas Budaya, Bandung: Rekatama Media

Moleong, L.J. 2001. Metodologi Penelitian Kualitatif. Bandung: PT. Remaja Rosdakarya.

Mulyana, Deddy dan Rakhmat Jalaluddin, 2005, Komunikasi Antarbudaya, Bandung, Rosdakarya

Patel, Fay, et al. 2011. Intercultural Communication (Building a Global Community). London: Sage Publication

Sudjarwo. (2001). Metodologi Penelitian Sosial. Bandung: Mandar Maju.

Sugiono. 2013. Metode Penelitian Pendidikan: Pendekatan Kuantitatif, Kualitatif, dan R \& D. Bandung: Alfabeta.

Syaiful Rohim, 2009. Teori Komunikasi Perspektif, Ragam, Aplikasi, Jakarta: Rineka Cipta

Verderber, Rudolph F., dan Kathleen S. Verderber, 1998. Inter-Act Using Interpersonal Communication Skill (Eight Edition). California: Wadsworth Publishing Company

\section{Jurnal}

Hadawiyah, Komunikasi Antarbudaya Pasangan Beda Etnis (Studi Fenomenologi Pasangan beda Etnis Suku Sulawesi - Jawa di Makassar), Jurnal Lentera Komunikasi, Vol 2 no 1 Agustus 2016, ISSN 2442-2991

Rostini Anwar, Hafied Cangara, Rintangan Komunikasi Antar Budaya Dalam Perkawinan Dan Perceraian Etnis Jawa Dengan Papua Di Kota Jayapura (Suatu Strategi Manajemen Konflik Dalam Hubungan Interpersonal Pasangan Suami Istri), Jurnal Komunikasi Kareba, Vol 5 no 2 Juli - Desember 2016, ISSN 2528-2891

\section{Website}

http://data.jakarta.go.id/dataset/data-jumlah-penduduk-asing-sementara-di-dkijakarta/resource/feb91f02-a8cb-4252-bd87-97c3ba7015c7 